\title{
Dosimetric Comparison of Volumetric Modulated Arc Therapy (VMAT) and Helical Tomotherapy for Hippocampal-Avoidance Prophylactic Whole Brain Radiotherapy (HA-PWBRT) in Small Cell Lung Cancer; Treatment Plans Based Study
}

\section{Küçük Hücreli Akciğer Kanserinde Hipokampüs-Korumalı Profilaktik Tüm Beyin Radyoterapisinin (HA-PWBRT) Volumetrik Ark Tedavisi ve Helikal Tomoterapinin Dozimetrik Karşılaştırması; Tedavi Planlarına Dayalı Çalışma}

\author{
Ozlem Yetmen Dogan $\odot$, Nilsu Cini ${ }^{\oplus}$, Sevecen Seyhun Nasır Can ${ }^{\oplus}$ \\ Saglık Bilimleri University, Kartal Dr Lutfi Kırdar Training And Research Hospital, Radiation Oncology Department, istanbul, Turkey
}

Received: 24.05.2020 / Accepted: 11.08.2020 / Published Online: 30.09.2020

Cite as: Yetmen Dogan O, Cini N, Nasır Can SS. Dosimetric comparison of volumetric modulated arc therapy (VMAT) and Helical tomotherapy for hippocampalavoidance prophylactic whole brain radiotherapy (HA-PWBRT) in small cell lung cancer: Treatment plans based study. Med J Bakirkoy 2020;16(3):263-71.

ABSTRACT

Objective: To carry out a dosimetric evaluation of two different advanced radiotherapy modalities prophylactic-whole brain radiotherapy with hippocampal avoidance in the treatment of patients with small cell lung cancer (SCLC).

Method: Computed tomography with fused magnetic resonance images of patients who were diagnosed with SCLC without brain metastasis were combined and re-planned with volumetric-modulated arc (VMAT) and also helical tomotherapy $(n=10)$. Doses of 25 Gy were prescribed in 10 fractions for the whole brain volume. Planning was performed according to RTOG 0933 criteria for hippocampal avoidance (Dmax $\leq 16 G y$, D100\% $\leq 9 G y)$. Planning target volume (PTV), homogeneity index (HI), conformity index (CI), minimum dose (Dmin) maximum dose (Dmax) and dose for organs at risk (OARs) were compared.

Results: In the analysis of PTV data, no significant difference was found between the helical tomotherapy and VMAT for D95 values, the minimum, maximum and mean values of PTV brain doses were higher in the VMAT arm $(p=0,000)$. When comparing PTV HI and Cl values, VMAT was significantly superior in $C I$ value $(p=0.033)$, but there was no significant superiority in $\mathrm{HI}$ values $(p=0.499)$. When compared statistically, and radiation doses delivered to hippocampus were evaluated it was seen that helical tomotherapy provided significantly better hippocampal protection than VMAT (right: 6.43Gy vs 8.94Gy; p=0.000; left: 6.10Gy vs 8.96Gy; $p=0.000$ ), mean (right 7.60Gy vs $11.42 \mathrm{~Gy} ; p=0.000$; left: $7.56 \mathrm{~Gy}$ vs $11.70 \mathrm{~Gy} ; p=0.000$ ) and maximum (right: $15.83 \mathrm{~Gy}$ vs $20.8 \mathrm{~Gy} ; p=0.003$; left: $15.99 \mathrm{~Gy}$ vs 20.13Gy; $p=0.009$ ). When analyzing lens doses, it was observed that the mean and maximum dose values of both right and left lenses were much lower in helical tomotherapy (mean right: 4.52 Gy vs $12,34 G y ; p=0,000$ and left: 4.66 Gy vs $11.69 G y ; p=., 000 ;$ maximum right: $3.41 G y$ vs $10.54 G y ; p=0.00$ and left: $3.53 G y$ vs $10.10 G y ; p=0,000$.

Conclusion: Acceptable treatment plans have been developed in both radiotherapy methods. Both hippocampus avoidance region and lens doses were found to be significantly superior in helical tomotherapy when compared with VMAT.

Keywords: dosimetry, hippocampal avoidance, VMAT, helical tomotherapy

öz

Amaç: Küçük hücreli akciğer kanseri hastalarının tedavisinde hipokampüs koruması ile profilaktik-tüm beyin radyoterapisinin iki farklı ileri radyoterapi tekniği ile dozimetrik olarak değerlendirmesi amaçlanmaktadır.

Yöntem: Beyin metastazı olmayan küçük hücreli akciğer kanseri teşhisi konulan, 10 hastanın bilgisayarlı tomografi ile manyetik rezonans görüntüleri ile birleştirilerek hacimsel ark tedavisi (VMAT) ve helikal tomoterapi ile yeniden planlandı. Tüm beyin hacmine 10 fraksiyonda 25 Gy dozu reçete edildi. Hipokampüs koruması için RTOG 0933 kriterlerine göre planlama yapıldı (Dmax $\leq 16 G y$, D100\% $\leq 9$ Gy). Planlanan hedef hacmi (PTV), homojenite indeksi (HI), uygunluk indeksi (CI), maksimum doz (Dmax), minimum doz (Dmin) ve risk altındaki organların (OAR) aldıkları dozlar karsılasstıııldı.

Bulgular: PTV verilerinin analizinde, helikal tomoterapi ve VMAT arasında D95 değerleri için anlamlı bir fark bulunmadı ( $p=0,141)$, VMAT kolunda PTV beyin dozlarııın minimum, maksimum ve ortalama değerleri daha yüksekti $(p=0,000)$. PTV; $\mathrm{HI}$ ve Cl değerleri karşılaştırıldığında, VMAT Cl değerinde önemli ölçüde üstündü ( $p=0.033$ ), ancak HI değerlerinde önemli bir üstünlük yoktu ( $p=0.499)$. istatistiksel olarak karsılasstırıldığında, hipokampus minimum (Sağ: 6,43Gy\&8,94Gy; $p=0,000$; Sol: 6,10Gy\&8,96Gy; $p=0,000$ ), ortalama (Sağ:7,60Gy\&11,40Gy; $p=0,000$; Sol: 7,56Gy\&11,70Gy; $p=0,000$ ) ve maksimum (Sağ: 15,83Gy\&20,8Gy; $p=0,003$; Sol: $15,99 \mathrm{~Gy} \& 20,13 \mathrm{~Gy} ; p=0,009)$ değerlerine bakıldığında helikal tomoterapi, VMAT'den önemli ölçüde daha iyi hipokampüs koruması sağladığı görüldü̈. Lens dozları analiz edildiğinde, sağ ve sol lenslerin ortalama ve maksimum doz değerlerinin helikal tomoterapide çok daha düsük olduğu gözlendi (Ortalama Sağ: 4,52Gy\&12,34Gy; $p=0,000$ ve Sol :4,66Gy \&11,69Gy; $p=0,000 ;$; Maksimum Sağ:3,41Gy\&10,54Gy; $p=0,000$ ve Sol: 3,53Gy\&10,10Gy; $p=0,000$ ).

Sonuç: Her iki radyoterapi yönteminde de kabul edilebilir tedavi planları geliştirilmişstir. Hem hipokampus korunması hem de lens dozları helikal tomoterapide VMAT'den anlamlı olarak daha üstün olduğu görüldü.

Anahtar kelimeler: dozimetri, hipokampus koruması, VMAT, helikal tomoterapi

Corresponding Author:

dryetmen@gmail.com
Ö. Y. Dogan 0000-0002-2733-0427

N. Cini $0000-0001-6370-6535$
S. S. N. Can 0000-0002-7801-3165

(C) Telif hakkı Sağlık Bilimleri Üniversitesi Bakırköy Dr. Sadi Konuk Eğitim ve Araştırma Hastanesi'ne aittir. Logos Tıp Yayıncılık tarafindan yayınlanmaktadır. Bu dergide yayınlanan bütün makaleler Creative Commons Atff-GayriTicari 4.0 Uluslararası Lisansı ile lisanslanmıştır.

(c) Copyright Health Sciences University Bakırköy Sadi Konuk Training and Research Hospital. This journal published by Logos Medical Publishing.

Licenced by Creative Commons Attribution-NonCommercial 4.0 International (CC BY) 


\section{INTRODUCTION}

PProphylactic whole brain irradiation (PWBRT) that decreases brain metastasis is administered as a treatment for patients with limited stage small cell lung cancer (SCLC) ${ }^{(1)}$ and also patients with extensivestage SCLC who respond to systemic therapy ${ }^{(2)}$. PWBRT is widely used in patients with SCLC. The findings in a study showed that PWBRT could prolong survival of the patients and only a mild reaction to chemotherapy could be observed ${ }^{(3)}$. Using PWBRT for patients with non-small-cell lung cancer (NSCLC) has recently taken considerable attention because PWBRT is likely to lessen the incidence of brain metastasis, but PWBRT does not prolong survival of the patients ${ }^{(4,5)}$.

Whole brain radiotherapy (WBRT) is mainly administered for patients who have many brain metastases that arose from various malignancies ${ }^{(6)}$. The development of WBRT cerebellar dysfunction, short-term memory and reduced ability to learn may lead to various side effects, such as disorders in neurocognitive functions ${ }^{(7,8)}$. The hippocampus has a vital effect on memory consolidation and emotional learning $(9,10)$. In the subgranular zone, the interruption of neurogenesis may bring on damaged memory ${ }^{(11-14)}$. The harm that arises from radiation to the hippocampus unfavourably affects cognitive function ${ }^{(15-17)}$.

With the novel radiation technologies like dynamic intensity-modulated radiation therapy (dIMRT) and step-and-shoot intensity-modulated radiotherapy (sIMRT) volumetric-modulated arc therapy (VMAT), and helical tomotherapy that were used to prevent the loss of neuronal stem cells arising from radiation exposure. Hippocampal- avoidance (HA) radiation techniques are developing day by day. We should note that the first data in the literature that was obtained from helical tomotherapy or LINAC-based intensity-modulated radiotherapy (IMRT) have already verified practicality of the method used $(18,19)$. Sood et al.'s findings showed the practicality of WBRT using VMAT both to spare the hippocampus and also decrease dose to OARs significantly (e.g., parotid glands, cochleae, scalp and ear canal) (20). Tomotherapy brings a homogeneous dose delivery to the whole brain and evades the hippocampus in a conformal manner ${ }^{(21)}$. However, surprisingly, in the literature, it is still not conclusive which approach is the most proper HA-PWBRT approach for VMAT and helical tomotherapy for patients with SCLC, which should be further investigated. To shed light into the literature, in this study, a dosimetric comparison has been made between VMAT and helical tomotherapy to investigate the technical advantages regarding the two treatment modalities in HA-PWBRT.

\section{MATERIAL and METHODS}

\section{Study design}

This study was approved by Ethics committee of SBU Kartal Dr Lütfi Kırdar Training and Research Hospital (2020/514/174/3). This study was a radiotherapy planning study aimed at testing the HA-WBRT planning technique with VMAT and helical tomotherapy.

\section{Population:}

Ten patients who were previously treated with HA-WBRT, according to the RTOG 0933 protocol, using helical tomotherapy whose treatment was re-planned with VMAT technique and compared to helical tomotherapy treatment plans.These ten patients who were treated between September 2018 and February 2019 and who did not have brain metastasis by magnetic resonance imaging (MRI) were included in the study. All patients had been histologically diagnosed with small cell lung cancer (SCLC), seven of them were in limited stage and 3 were in extensive stage

\section{Simulation and contouring}

In this study, computed tomography (CT) data were obtained following RTOG 0933 criteria. All of the patients in this study had MRI with axial T2-weighted and gadolinium contrast-enhanced T1-weighted sequences for hippocampus contouring with slice thickness not extending $1.5 \mathrm{~mm}$. To obtain a CT simulation with a slice thickness of $1.25 \mathrm{~mm}$, the patients were immobilized in the supine position. The MRI images were semi-automatically fused to the simulation CT by the radiation oncologist in the Eclipse planning system (Varian Medical Systems, Palo Alto, CA, USA). Contouring was performed with 2D and 3D brushes on axial images. Contours for targets and other normal structures which encompassed the brainstem, eyes, cord, chiasm, brain, optic nerves lenses, and external patient contour w/ 
immobilization devices, were contoured in treatment contouring system SomoVision (Varian Medical Systems, Palo Alto, CA,USA)

Hippocampus was contoured taking into account of RTOG shaping guides. The hippocampus head and amygdala are located in the gray matter on the other side of the temporal horn. At the level of the pons and pituitary gland, lower part of the hippocampus was located. Contours were ended at the splenium of the corpus callosum (Clinical target volumehippocampal avoidance: CTV-HA). Planning target volume-hippocampal avoidance (PTV-HA) zone was produced with $5 \mathrm{~mm}$ contour widening from CTVHA. The whole brain PTV with the hippocampal avoidance region was created by subtracting this PTV$\mathrm{HA}$ region from the brain parenchyma to $\mathrm{C} 1$ and $\mathrm{C} 2$. The same radiation oncologist defined the contours and the contours were also peer reviewed. Afterwards, the contours in sagittal, coronal and axial projections were rechecked by a neuroradiologist. Before starting treatment, according to the protocol, the dose up to $100 \%$ of the hippocampal dose should not be more than $9 \mathrm{~Gy}$, the maximal hippocampal dose should not be more than $16 \mathrm{~Gy}$. It was stated that $100 \%$ of the hippocampus that exceeded $10 \mathrm{~Gy}$ and the maximum hippocampal dose that exceeded17 Gy were unacceptable and re-planning was required.

\section{HA-PWBRT Planning technique}

\section{Volumetric ARC (VMAT) technique:}

The VMAT plans were created with the Trilogy (Varian Medical Systems Inc, Palo Alto, USA) linac with a maximum rate of $600 \mathrm{MU} /$ min with 120 high resolution multi-leaf collimator (MLC) with a central width of $2.5 \mathrm{~mm}$ in $10 \times 10$ areas and $5 \mathrm{~mm}$ leaf width in others. The VMAT technique offers single or multiple volumetric modulation arcs with varying portal speeds, dose rates and MLC leaf movement speeds to achieve optimum target coverage. Treatment plans were optimized and calculated using Eclipse (Varian Medical Systems, Inc) TPS version 13.7.0 and an Anisotropic Analytical Algorithm (AAA). Each plan for this study consisted of six non-planar arcs with collimator angle rotations of 30 and 330 degrees, gantry angles of 181 to 179 and 181 to 340 degrees, and couch rotations of 10,270 and 350 degrees. We used the Arc Geometry Tool to create arcs. The
Progressive Resolution Optimizer (version 13.7.10) used for VMAT optimization ${ }^{(22)}$.

\section{Helical Tomotherapy Technique:}

The helical Tomotherapy plans were created for the treatment planning workstation (Precision 1.1.0.0; Accuray,, Sunnyvale, CA, USA) with the Collapsed Cone Convolution / Superposition algorithm using $6 \mathrm{MV}$ unflattened photon beam by 64 dual multi-leaf collimators). All helical tomotherapy plans are designed for each patient: $2.5 \mathrm{~cm}$-dynamic jaw and plans have a step value in the range of 0.172 to 0.225 and a modulation factor in the range of 1.6 to $3^{(23)}$.

\section{Statistical analysis:}

Statistical analysis and comparisons between the treatment plans of two different irradiation techniques were performed using a one-way Analysis of Variance (ANOVA) and SPSS Version 21 statistical software (IBM, USA) In order to be statistically significant, $p$ values must be below $p<.05^{(24)}$.

\section{RESULTS}

In the study, HA-PWBRT radiotherapy plans of 10 male patients were compared. The mean age of patients receiving radiotherapy treatment was 56.3 (range; 47-68) years. Seven patients had limited stage SCLC and 3 patients extensive-stage SCLC.The mean total brain volume was $1396 \mathrm{cc}$, volumes of the right, and left hippocampi were $1.55 \mathrm{cc}$, and 1.59 $\mathrm{cc}$, respectively. For the treatment of HA- PWBRT irradiation, the total treatment dose for each patient was planned to be $25 \mathrm{~Gy} / 10$ fractions (Table 1).

Table 1. Patient characteristics of HA-PWBRT.

\begin{tabular}{ll}
\hline Gender of Total Patients & Male 10 /10 \\
\hline Pathology of the Total Patients & $\begin{array}{l}\text { Limited- Stage SCLC 7/10 } \\
\text { Extensive-Stage SCLC 3/10 }\end{array}$ \\
\hline Average Age of Total Patients & 56.3 (47-68) \\
\hline Total Treatment Dose & $25 G y / 10$ fractions \\
\hline $\begin{array}{l}\text { Total Brain Volume } \\
\text { Mean of Total Patients }\end{array}$ & $1396 \mathrm{cc}$ \\
\hline $\begin{array}{l}\text { Hippocampus Right Volume } \\
\text { Mean of Total Patients }\end{array}$ & $1.55 \mathrm{cc}$ \\
\hline $\begin{array}{l}\text { Hippocampus Left Volume } \\
\text { Mean of Total Patients }\end{array}$ & $1,59 \mathrm{cc}$ \\
\hline
\end{tabular}


Table 2. Treatment characteristics of the HA-PWBRT with Helical Tomotherapy \&VMAT.

\begin{tabular}{|c|c|c|c|c|}
\hline Structure & Dosimetric Parameter & Helical Tomotherapy & VMAT & $p$ value \\
\hline \multirow[t]{6}{*}{ PTV } & D95 & 23,01 & 23,77 & $p=0.141$ \\
\hline & minimum & 5,99 & 8,99 & $p=0,000$ \\
\hline & maximum & 28,34 & 33,75 & $p=0,000$ \\
\hline & mean & 26,52 & 28,75 & $p=0,000$ \\
\hline & $\mathrm{HI}$ & 0,39 & 0,37 & $p=0.499$ \\
\hline & $\mathrm{Cl}$ & 1,17 & 1,09 & $p=0.033$ \\
\hline \multirow[t]{3}{*}{ Right Hippocampus } & minimum & 6,13 & 8,94 & $p=0,000$ \\
\hline & maximum & 15,83 & 20,80 & $p=0,003$ \\
\hline & mean & 7,60 & 11,42 & $p=0,000$ \\
\hline \multirow[t]{3}{*}{ Left Hippocampus } & minimum & 6,10 & 8,96 & $p=0,000$ \\
\hline & maximum & 15,99 & 20,13 & $p=0,009$ \\
\hline & mean & 7,56 & 11,70 & $p=0,000$ \\
\hline \multirow[t]{2}{*}{ Right Lens } & maximum & 3,41 & 10,54 & $p=0,000$ \\
\hline & mean & 4,52 & 12,34 & $p=0,000$ \\
\hline \multirow[t]{2}{*}{ Left Lens } & maximum & 3,53 & 10,19 & $p=0,000$ \\
\hline & mean & 4,66 & 11,69 & $p=0,000$ \\
\hline
\end{tabular}

Dose-volume values obtained from patient plans were compared using two different radiotherapy treatment methods.In this study, the hippocampus (left-right); lens (left-right); Planning target volume (PTV); maximum, minimum and mean dose, the dose of $95 \%$ of the volume (D95) PTV, homogeneity index ( $\mathrm{HI})$ and conformity index $(\mathrm{Cl})$ were analyzed and two radiotherapy techniques were compared in terms of these parameters.

As a result of the analyzes, in the comparison of two modalities it is seen that the average of minimum (tomotherapy TPS; Right: 6,13 Gy; Left: 6,10 Gy \& VMAT TPS; Right: 8,94Gy; Left: 9,96 Gy p right $=0,000 \&$ p left: 0,000), mean (Tomotherapy TPS; Right: 7,6 Gy; Left:6,10 Gy \& VMAT TPS; Right: 11,4Gy; Left: 11,7 Gy; $p$ right $=0,000 \& p$ left: 0,000 ) and maximum (Tomotherapy TPS; Right: $15.8 \mathrm{~Gy}$; Left: 15,8 Gy \& VMAT TPS; Right: 20,8Gy; Left: 20,13Gy; p right $=0,003 \& p$ left: 0,009 ) dose values of both right and left hippocampus regions were lower than the values obtained from tomotherapy treatment planning system (TPS) (Table 2). When compared statistically, according to the $p$ values of hippocampus minimum (Right $\mathrm{p}=0,000$; Left $\mathrm{p}=0,000$ ), mean (Right $p=0,000$; Left $p=0,000$ ) and maximum (Right $p=0.003$; Left $p=0.009$ ) shows that tomotherapy TPS provides significantly better hippocampal protection than VMAT TPS (Table 2, Figure 1, 2).

For the analysis of the lens doses it was observed that mean and maximum doses of both right and left lenses were lower than the values obtained from helical tomotherapy TPS. The maximal and mean doses were as follows: right lens; 3,41Gy,4,52Gy, and 10,54 Gy,12,34Gy and left lens; 3,53Gy,4,66Gy and 10,19Gy,11,69Gy for helical tomotherapy and VMAT, respectively. Statistically, both $p$ values of the right lens (mean $p=0,000$, maximum $p=0,000$ ) and the left lens (mean $p=0,000$, maximum $p=0,000$ ) reveal that helical tomotherapy TPS lens protection is significantly superior than the VMAT TPS (Figure 1, 2).

In the analyzes of the PTV data, there is no significant difference $(p=0,141)$ for the D95 values between tomotherapy and VMAT TPS. On the other hand for the PTV minimum $(p=0,000)$, maximum $(p=0,000)$ and mean $(p=0,000)$ values were significantly higher in the VMAT TPS arm. When PTV $\mathrm{HI}$ and $\mathrm{Cl}$ values were compared, VMAT TPS was significantly superior $(p=0.033)$ in the $\mathrm{Cl}$ value, but no significant superiority was detected in $\mathrm{HI}$ values $(p=0.499)$ (Table 2). 

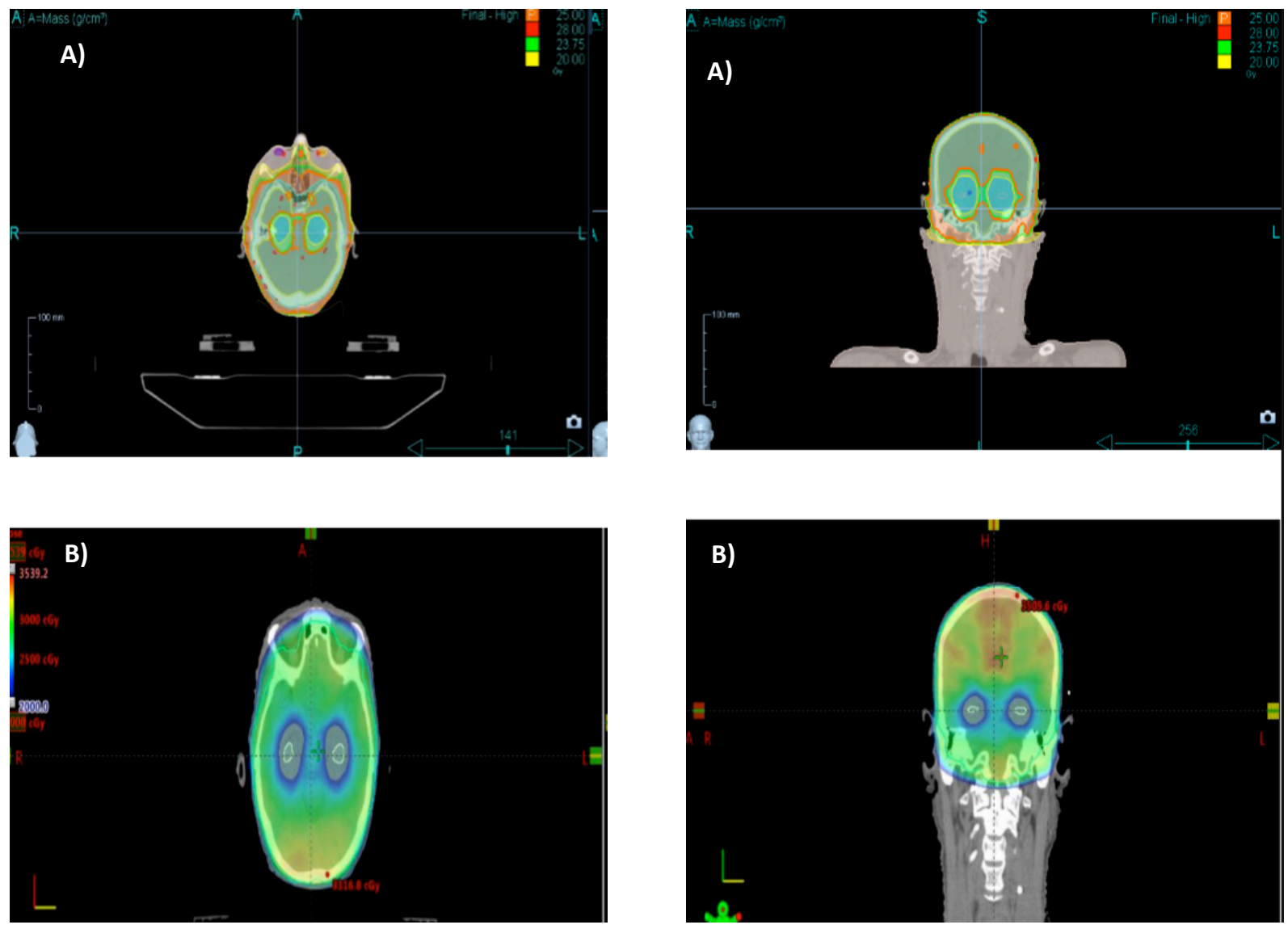

Figure 1. Color wash comparison of dose distributions for two modalities in a representative patient.

A; Helical Tomotherapy,

B; VMAT: Volumetric-Modulated Arc Therapy
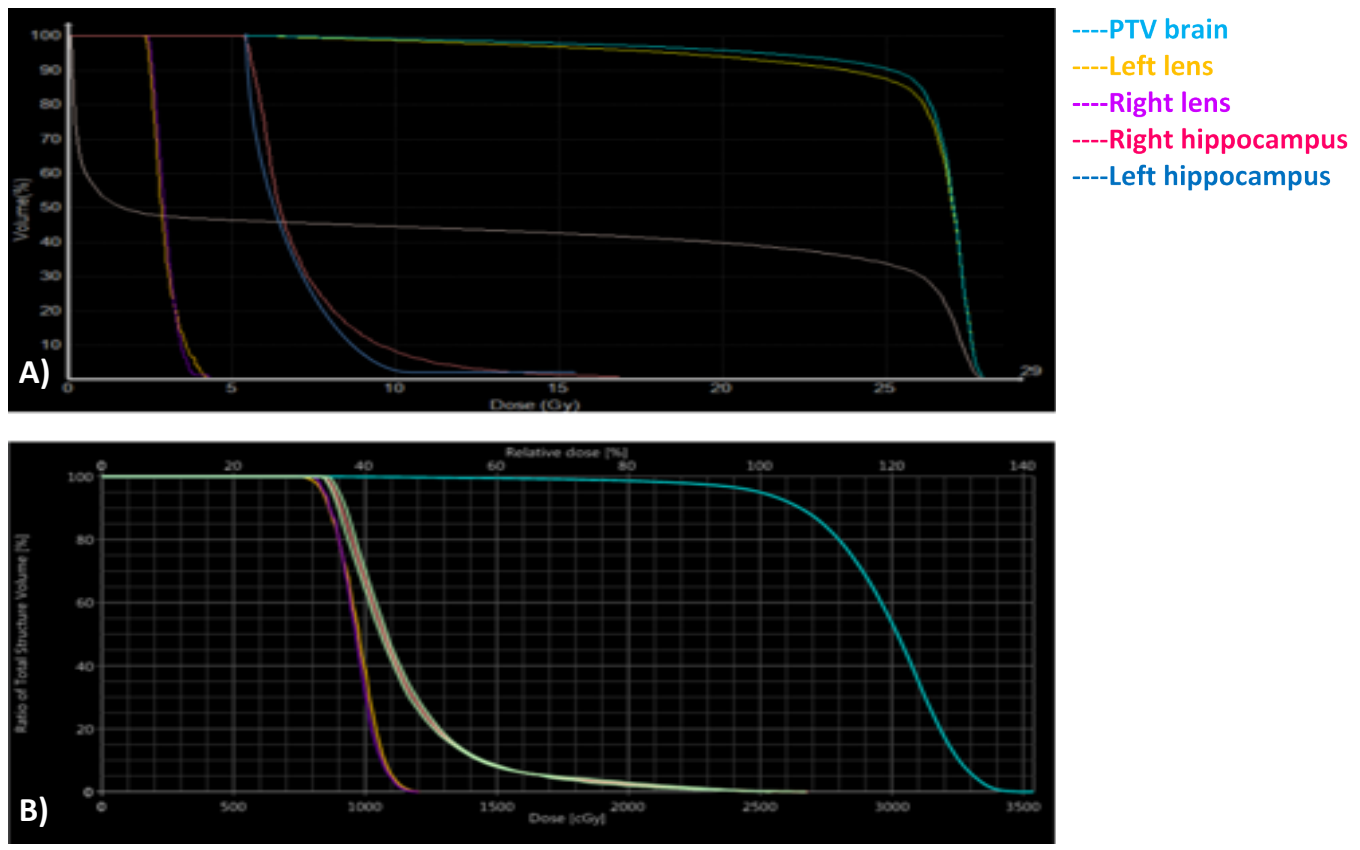

Figure 1. Color wash comparison of dose distributions for two modalities in a representative patient.

A; Helical Tomotherapy,

B; VMAT: Volumetric-Modulated Arc Therapy 


\section{DISCUSSION}

The degree of the harm that arises from radiation doses delivered to the organs at risk (OARs) has been overlooked in the literature. Thanks to the improvement in the sIMRT, dIMRT, VMAT and helical tomotherapy, recently, we can reduce neurocognitive toxicity and deficits of the OARs Studies have reported that harm to the hippocampus that arises from radiation exposure may have a vital effect on the cognitive decline of the patients. Deficits in learning and memory were seen in the patients that were administered whole brain radiotherapy which were discussed, and suggested to be associated with the hippocampal injury ${ }^{(25)}$. We highlighted the dosimetric benefits of two advanced radiotherapy modalities (VMAT and helical tomotherapy TPS) with the hippocampus and OARs so as to use this treatment of PWBRT in the present study.

In our study, the PTV minimum $(\mathrm{p}=0,000)$, maximum $(p=0,000)$ and mean $(p=0,000)$ values were significantly higher in the VMAT TPS arm. When the PTV HI and $\mathrm{Cl}$ values were compared, VMAT TPS was found to be statistically significantly superior $(p=0.033)$ in the $\mathrm{Cl}$ value, but without any significant superiority in HI values $(p=0.499)$. Helical Tomotherapy TPS can provide a better dose distribution in the PTV brain compared to the VMAT TPS, as Cozzi et al. reported ${ }^{(26)}$.

The helical tomotherapy and IMRT in hippocampal sparing whole brain radiotherapy were investigated by Gondi et al. to compare their effectiveness. Their findings showed that the target volume coverage and OAR-sparing were comparable in the two techniques. However, the median dose of $5.5 \mathrm{~Gy}$ and the maximum dose of 12.8 Gy were received by the hippocampus. For helical Tomotherapy, it was 7.8 and for IMRT, it was $15.3 \mathrm{~Gy}{ }^{(19)}$. In the present study, the same results were found. Considering the radiation doses received by hippocampus, minimum (tomotherapy TPS; Right: 6.13 Gy; Left: 6.10 Gy \& VMAT TPS; Right: $8.4 \mathrm{~Gy}$; Left:9.96 Gy $p$ right $=0.000 \& \mathrm{p}$ left: 0.000), mean (Tomotherapy TPS; Right:7.6 Gy; Left: $6.10 \mathrm{~Gy}$, and VMAT TPS; Right: $11.4 \mathrm{~Gy}$; Left: $11.7 \mathrm{~Gy}$; $\mathrm{p}$ right $=0.000 \& \mathrm{p}$ left:0.000) and maximum (Tomotherapy TPS; Right: $15.8 \mathrm{~Gy}$; Left:15.8 Gy , and VMAT TPS; Right: 20,8Gy; Left:20,13Gy; p right= $0,003 \& p$ left: 0,009 ) doses show that helical tomot- herapy TPS provides significantly better hippocampal protection than VMAT TPS.

Rong et al. ${ }^{(24)}$ assessed the potential dosimetric differences among three modalities, namely IMRT, helical tomotherapy and VMAT, in providing HA-WBRT. When we evaluated hot spots to plan target volume (PTV), and compared with helical tomotherapy, the average dose administered to $2 \%$ of PTV (D2\%) for IMRT was not superior to VMAT given that both IMRT and VMAT indicated a significantly higher D2\%. In the present study, PTV minimum and maximal doses were 8.99Gy, 5,99 Gy and $33.75 \mathrm{~Gy}, 28,34$ Gy for VMAT and helical tomotherapy TPS, respectively. With the same results, Rong et al. showed that PTV provided better dose distribution in helical tomotherapy TPS than VWAT TPS.

Rong et al. showed that helical tomotherapy had a considerably better homogeneity index (HI) of 0.15 , and 0.03 when they compared with IMRT and VMAT (24). However, in the present study, we could not find any difference in $\mathrm{HI}(0.39 \& 0,37 \mathrm{p}=0,5)$, but in the conformity index $(\mathrm{Cl})$, VMAT TPS has better coverage than helical tomotherapy TPS. In terms of hippocampal avoidance, in their study, Rong et al. calculated that IMRT (8.7 Gy) and VMAT (8.6 Gy) had a higher mean dose when compared to helical tomotherapy $(8.0 \mathrm{~Gy}){ }^{(24)}$. In the present study, helical tomotherapy and VMAT TPS right (7,6Gy and 11.4Gy) and left (7.56Gy and 11.7Gy) hippocampal doses are better dose calculation than VMAT TPS $(p=0,000)$. In this study, helical tomotherapy and VMAT TPS were used for the calculation of the right (7.6Gy and 11.4Gy) and left (7.56Gy and 11.7Gy) hippocampal doses, respectively. As a result, helical tomotherapy has better dose distribution than VMAT TPS $(p=0,000)$.

When the OAR-sparing impacts were evaluated, VMAT delivered higher doses on lenses than helical tomotherapy. The maximal doses delivered were as follows: right lens 3.41Gy vs $10.54 \mathrm{~Gy}$ and left lens 3.53Gy vs $10.19 \mathrm{~Gy}$ for helical tomotherapy and VMAT, respectively. In our study for both lenses, the maximum and mean VMAT TPS doses were significantly higher than helical tomotherapy $(p=0,000)$, as shown by Rong et al. ${ }^{(24)}$. Besides sparing the hippocampus on helical tomotherapy HA-PWBRT plans, for helical tomotherapy plan optimization, to decre- 
ase dose to OARs without making a compromise with the HA-PWBRT-PTV coverage, the doses to OARs were administered. When compared with VMAT TPS, statistically significant dose reductions ( $p$ $<0.001$ ) to OARs were detected. Sood et al. calculated mean dose to the hippocampus as 8.4Gy, and the maximum dose as $15.6 \mathrm{~Gy}$ without making a compromise with the WB-PTV coverage in line with the RTOG guidelines ${ }^{(18,20)}$. Our findings showed considerable dose reductions on other OARs, including both right and left lenses compared with VMAT TPS. However, in this study, VMAT TPS provided conformity and dose homogeneity as those found in helical tomotherapy, but higher lens and hippocampal doses were calculated compared to helical tomotherapy TPS.

Gondi et al. conducted research on the effectiveness regarding only helical tomotherapy and the IMRT methods. Their findings showed that treatment modalities were effective for WBRT and there were not any differences about the effectiveness level in two methods ${ }^{(19)}$. However, in this study, our findings showed that helical tomotherapy TPS was significantly more efficacious in decreasing the minimum hippocampal dose than VMAT TPS. The findings obtained in this study are compatible with published research that indicated that helical tomotherapy indicated an enhanced potential for the selective sparing of tissue in comparison with VMAT TPS.

In their study, Jiang et al. showed that 4 planning modalities (sIMRT, dIMRT, VMAT and Tomo) satisfied the RTOG 0933 protocol dose compatibility criteria for hippocampal sparing. Using the planning modalities reported above with an acceptable mean PTV brain coverage (88.2\%-92.6), delivery of similar mean doses to the hippocampi were accomplished ${ }^{(27)}$. In our study, in the comparison of two modalities (VMAT and helical tomotherapy), it is seen that the average of minimum, mean and maximum doses received by both right and left hippocampal regions are lower in helical tomotherapy treatment planning system (TPS). Also, they concluded that the inner ear dose was reduced to Dmean $\leq 15 \mathrm{~Gy}$ in all four planning modalities (27).

The dose of the lens during cranial radiotherapy depends on many factors. Patient-dependent factors are the distance between age and lens and the lateral bone quantus, and treatment-related factors as radiation quality, total dose, patient set-up errors, dose rate, and radiotherapy technique. The dose limit is considered to be about 4-8 Gy in adults and is especially important in patients undergoing prophylactic cranial irradiation ${ }^{(28,29)}$. Adult lens may tolerate a total of $5 \mathrm{~Gy}$ in radiotherapy applied in fractions; $50 \%$ probability is about $15 \mathrm{~Gy}$, which will cause clinical problems in vision. In our study, both the lens doses were observed, and mean and maximum doses lower in helical tomotherapy TPS. Statistically, both doses of the right (maximum dose 3,41Gy) and the left lenses (maximum dose 3,53Gy) reveal that, lens protection in helical tomotherapy TPS is significantly superior to the VMAT TPS.

Ongoing randomized multicenter phase III trial (NCT02397733) performed with patients with SCLC to be received $\mathrm{PCl}$ treatment or $\mathrm{PCl}$ with hippocampus prevention with intensity-modulated radiation therapy or volumetric modulated arc therapy so as to to assess the potential effects of $\mathrm{PCl}$ with hippocampal avoidance for the neurocognitive function and life quality of the patients with SCLC ${ }^{(30)}$. The doses that were administered in their study were the same doses we have administered in the present study as follows: maximum dose was $16 \mathrm{~Gy}$ and the hippocampus optimum D100\% dose was $9 \mathrm{~Gy}$.

\section{Conclusions}

Our data showed that all two HA-PWBRT modalities (VMAT and helical tomotherapy) are likely to produce acceptable treatment plans with satisfactory PTV brain coverage. In this retrospective study, it has been found that helical tomotherapy not only protects the hippocampus better than VMAT TPS in HA-PWBRT but also significantly reduces lens doses. Abbreviations

$\mathrm{Cl}$ : conformity index; $\mathrm{CT}$ : computed tomography; CTV: clinical target volume; Dmax: maximum dose; Dmin: minimum dose; DVH: dose-volume histogram; HI: homogeneity index; MRI: magnetic resonance imaging; NSCLC: non-small cell lung cancer; OARs: dose to organs at risk; PTVbrain: planning clinical target volume; VMAT: volumetric-modulated arc therapy; HA-PWBRT: Hippocampal Avoidance 
Prophylactic Wholebrain radiotherapy, TPS:Treatment Planning System

Ethics Committee Approval: This study approved in SBU Kartal Dr Lütfi Kırdar Training and Research Hospital 2020/514/174/3).

Conflict of Interest: None declared.

Funding: This research did not receive any specific grant from funding agencies in the public, commercial, or not-for-profit sectors.

Informed Consent: Informed consent was not obtained since the study is radiotherapy planned based.

\section{REFERENCES}

1. Auperin A, Arriagada R, Pignon JP, et al. Prophylactic cranial irradiation for patients with small-cell lung cancer in complete remission. Prophylactic cranial irradiation overview collaborative group. N Engl J Med. 1999;341(7):476-84.

https://doi.org/10.1056/NEJM199908123410703

2. Slotman BJ, Faivre-Finn C, Kramer GW, et al. Prophylactic cranial irradiation in extensive small cell lung cancer. N Engl J Med. 2007;357(7):664-72.

https://doi.org/10.1056/NEJMoa071780

3. Arruda Viani G, Campiolo Boin A, Yuri Ikeda V, et al. Thirty years of prophylactic cranial irradiation in patients withsmall cell lung cancer: a meta-analysis of randomized clinical trials. J Bras Pneumol. 2012;38(3):372-81.

https://doi.org/10.1590/S1806-37132012000300013

4. Pöttgen C, Eberhardt W, Grannass A, et al. Prophylactic cranial irradiation inoperable stage IIIA non-small-cell lung cancer treated with neoadjuvant chemoradiotherapy: results from a German multicenter randomized trial. J Clin Oncol. 2007;25(31):4987-92. https://doi.org/10.1200/JCO.2007.12.5468

5. Gore EM, Bae K, Wong SJ, et al. Phase III comparison of prophylactic cranial irradiation versus observation in patients with locally advanced non-small-cell lung cancer: primary analysis of radiation therapy oncology group study RTOG 0214 . J Clin Oncol. 2011;29(3):272-8.

https://doi.org/10.1200/JCO.2010.29.1609

6. Nussbaum ES, Djalilian HR, Cho KH, Hall WA. Brain metastases. Histology, multiplicity, surgery, and survival. Cancer. 1996;78(8):1781-8. PMID: 8859192. https://doi.org/10.1002/(SICl)1097-0142(19961015) 78:8<1781::AID-CNCR19>3.0.CO;2-U

7. De Angelis LM, Delattre JY, Posner JB. Radiationinduced dementia in patients cured of brain metastases. Neurology. 1989;39(6):789-96. https://doi.org/10.1212/WNL.39.6.789

8. Roman DD, Sperduto PW. Neuropsychological effects of cranial radiation: current knowledge and future directions. Int J Radiat Oncol Biol Phys. 1995;31(4):98398.

https://doi.org/10.1016/0360-3016(94)00550-8

9. Marsh J, Gielda B, Herskovic A, et al. Sparing of the hippocampus and limbic circuit during whole brain radiation therapy: a dosimetric study using helical tomotherapy. J Med Imaging Radiat Oncol. 2010;54(4):375-82. https://doi.org/10.1111/j.1754-9485.2010.02184.x

10. Raineki C, Holman PJ, Debiec J, et al. Functional emergence of the hippocampus in context fear learning in infant rats. Hippocampus. 2010;20(9):1037-46. https://doi.org/10.1002/hipo.20702

11. Jeneson A, Mauldin KN, Hopkins RO, et al. The role of the hippocampus in retaining relational information across short delays: the importance of memory load. Learn Mem. 2011;18(5):301-5. https://doi.org/10.1101/Im.2010711

12. Hannula DE, Tranel D, Cohen NJ. The long and the short of it: relational memory impairments in amnesia, even at short lags. J Neurosci. 2006;26(32):8352-9. https://doi.org/10.1523/JNEUROSCI.5222-05.2006

13. Deng W, Saxe MD, Gallina IS, et al. Adult-born hippocampal dentate granule cells undergoing maturation modulate learning and memory in the brain. J Neurosci. 2009;29(43):13532-42.

https://doi.org/10.1523/JNEUROSCI.3362-09.2009

14. Hamilton GF, Murawski NJ, St. Cyr SA, et al. Neonatal alcohol exposure disrupts hippocampal neurogenesis and contextual fear conditioning in adult rats. Brain Res. 2011;1412:88-101. https://doi.org/10.1016/j.brainres.2011.07.027

15. Chang EL, Wefel JS, Hess KR, et al. Neurocognition in patients with brain metastases treated with radiosurgery or radiosurgery plus whole-brain irradiation: a randomised controlled trial. Lancet Oncol. 2009;10(11):1037-44.

https://doi.org/10.1016/S1470-2045(09)70263-3

16. Gondi V, Pugh SL, Tome WA, et al. Preservation of memory with conformal avoidance of the hippocampal neural stem-cell compartment during whole-brain radiotherapy for brain metastases (RTOG 0933): a phase II multi-institutional trial. J Clin Oncol. 2014;32(34):3810-6. https://doi.org/10.1200/JCO.2014.57.2909

17. Tang FR, Loke WK, Khoo BC. Post natal irradiationinduced hippocampal neuropathology, cognitive impairment and aging. Brain Dev. 2017;39(4):277-293. https://doi.org/10.1016/j.braindev.2016.11.001

18. Ghia A, Tomé W, Thomas S, et al. Distribution of brainmetastases in relationtothehippocampus: implications for neurocognitive functional preservation. Int J Radiat Oncol Biol Phys. 2007;68(4):971-7. https://doi.org/10.1016/j.ijrobp.2007.02.016

19. Gondi V, Tolakanahalli R, Mehta MP, et al. Hippocampalsparing whole brain radiotherapy: a "How-To" technique, utilizing helical tomotherapy and LINAC based intensity modulated radiotherapy. Int J Radiat Oncol Biol Phys. 2010;78(4):1244-52. https://doi.org/10.1016/j.ijrobp.2010.01.039

20. Sood S, Pokhrel D, McClinton C, et al. Volumetricmodulated arc therapy (VMAT) for whole brain radiotherapy: not only for hippocampal sparing, but also for reduction of dose to organs at risk. Med Dosim. 2017;42(4):375-83. https://doi.org/10.1016/j.meddos.2017.07.005

21. Gutiérrez AN, Westerly DC, Tomé WA, et al. Whole brain radiotherapy with hippocampal avoidance and 
simultaneously integrated brain metastases boost: a planning study. Int J Radiat Oncol Biol Phys. 2007;69(2):589-97.

https://doi.org/10.1016/j.ijrobp.2007.05.038

22. Bijina T K, Ganesh KM, Pichandi A, et al. Cyberknife, helical tomotherapy and rapid arc sib-sbrt treatment plan comparison for carcinoma prostate. Asian Pac J Cancer Prev. 2020;21(4):1149-1154.

https://doi.org/10.31557/APJCP.2020.21.4.1149

23. Zhang J, Peng $Y$, Ding $S$, et al. Comparison of different combinations of irradiation mode and jaw width in helical tomotherapy for nasopharyngeal carcinoma. Front Oncol. 2020;10:598.

https://doi.org/10.3389/fonc.2020.00598

24. Rong Y, Evans J, Xu-Welliver M, et al. Dosimetric evaluation of intensity-modulated radiotherapy, volumetric modulated arc therapy, and helical tomotherapy for hippocampal-avoidance whole brain radiotherapy. PLoS One. 2015;10(4):e0126222.

https://doi.org/10.1371/journal.pone.0126222

25. Monje ML, Mizumatsu S, Fike JR, et al. Irradiation induces neural precursor-cell dysfunction. Nat Med. 2002;8(9):955-62. https://doi.org/10.1038/nm749

26. Cozzi L, Clivio A, Bauman G, et al. Comparison of advanced irradiation techniques with photons for benign intracranial tumours. Radiother Oncol. 2006;80(2):268-73.

https://doi.org/10.1016/j.radonc.2006.07.012

27. Jiang A, Sun W, Zhao F, et al. Dosimetric evaluation of four whole brain radiation therapy approaches with hippocampus and inner ear avoidance and simultaneous integrated boost for limited brain metastases. Radiat Oncol. 2019;14(1):46.

https://doi.org/10.1186/s13014-019-1255-7

28. Henk JM, Whitelocke RA, Warrington AP, Bessell EM. Radiation dose to the lens and cataractformation. Int J Radiat Oncol Biol Phys. 1993;25(5):815-20. https://doi.org/10.1016/0360-3016(93)90310-R

29. Hempel M, Hinkelbein W. Eye sequelae following external irradiation. Recent Results Cancer Res. 1993;130: 231-6.

https://doi.org/10.1007/978-3-642-84892-6_20

30. de Dios NR, Couñago F, López JL, et al. Treatment Design and Rationale for a Randomized Trial of Prophylactic Cranial Irradiation With or Without Hippocampal Avoidance for SCLC: PREMER Trial on Behalf of the Oncologic Group for the Study of Lung Cancer/Spanish Radiation Oncology Group-Radiation Oncology Clinical Research Group. Clin Lung Cancer. 2018;19(5):e693-7.

https://doi.org/10.1016/j.cllc.2018.05.003 